\title{
Equivalence Problems in the Translation of Student Translators
}

\author{
Rusdi Noor Rosa ${ }^{1}$, Yetti Zainil ${ }^{2}$, Zul Amri ${ }^{3}$ \\ Universitas Negeri Padang \\ \{rusdinoorrosa@fbs.unp.ac.id ${ }^{1}$ \}
}

\begin{abstract}
This paper aims at finding out equivalence problems encountered by student translators in translating a historical recount text. This is a descriptive study using the translation of student translators as the data. The study took 30 student translators as the participants who were asked to translate a historical recount text from English into bahasa Indonesia. The data were collected using Translog and any uses of online resources were allowed. The data were analysed using error analysis technique. The results of the study found several equivalence problems in the translation of student translators including translating SL interference, ST misunderstanding, improper use of borrowing technique, meaning deletion and insufficient TL competence. The findings suggest further studies to investigate possible solutions to such equivalence problems.
\end{abstract}

Keywords: Equivalen Problems, Translation, Student, Translator

\section{Introduction}

Translation is intended to reproduce a text in a different language. The term "reproduce" implies that a translated text or target text (TT) should be equivalent in meaning with its source text (ST); in other words, a TT is not a newly created text. Translation is needed to accommodate people's limited access to a variety of information due to foreign language problem. Therefore, accurate translation is required to avoid any possible misleading information given to TL readers. Accuracy in translation is a prolonged debate among translation scholars since accuracy is both subjective ([1]; [2]) and relative ([3]; [4]). Nevertheless, accuracy is not an unsolved problem in translation. Using the idea of nothing absolute in translation [5], accuracy can be achieved under certain conditions. To reveal such conditions, a number of studies on translation accuracy have been conducted. Reference [6] found the applicable role of componential analysis to achieve translation accuracy. In addition, componential analysis is helpful to bridge the gap for culture differences [7]. In addition to human translation, other studies have also been conducted to examine the accuracy of translation performed by translation machines ([8]; [9]; [10]). They found that, despite their small number of weaknesses, translation machines are helpful in achieving accuracy in translation.

The notion of accuracy discussed in the previous paragraph is basically related to the reproduction of a text which is equivalent in meaning with its ST. Finding meaning 
equivalence is considered as the real definition of translation, so studying equivalence problems in translation should always be regarded useful. Besides, equivalence is a central problem encountered by translators during the translation process ([11]; [12]). Moreover, Reference [13] argues that producing non-equivalents in translation is inappropriate and distorts or blurs the meaning. The notion of equivalence has attracted many researchers to conduct studies on it. Most of studies were conducted to redefine the term equivalence in translation (e.g. [14]; [15]; [16]). Reference [16] who studied features and necessity of equivalence in translation, for example, found that equivalence in translation cannot be interpreted as identity in terms of its scientific sense because there are no words that have exactly the same meaning in one language. This means that studying equivalence should be established on different levels and in different aspects. In addition to redefining the concept of equivalence, other studies also investigate the issue of equivalence and non-equivalence in translation (e.g. [17]; [18]; [19]). Other studies were conducted to investigate the equivalence in TT. Reference [20] who analyzed the equivalence of the translated subtitle of Intel advertisements, for example, found that the TT was equivalent with its ST.

The previous studies mentioned above focus more on redefining the concept of equivalence and how it is realized in TT analysis, but pay less attention to the problem encountered by translators in achieving such equivalence. Considering the gap left in those previous studies, this study takes equivalence problems as the issue that needs to be investigated. In particular, this study aims at finding out equivalence problems encountered by student translators in translating a historical recount text from English into bahasa Indonesia. The choice of specific text genre as the object of investigation is motivated by the research conducted by Reference [15]. Besides, the choice of student translators as the participants is mainly motivated by previous studies suggesting that student translators have their own unique translation characteristics different from professional translators [21].

\section{Method}

This is a descriptive study conducted in the English Department of Universitas Negeri Padang. The data were the translation of student translators. 30 students who had taken translation courses were selected as the participants. They were asked to translate a historical recount text (downloaded from https://www.britannica.com/place/Machu-Picchu) from English as the ST into bahasa Indonesia as the TT. The data were collected using Translog for its effective use of recording the whole translation activities performed by the student translators, and the use of any online resources was allowed. The data were analysed using error analysis technique.

\section{Result and Discussion}

The results of data analysis found several equivalence-related problems in the translation of student translators. The first problem encountered by the student translators in translating the historical recount text from English into bahasa Indonesia is the SL interference in the TT. One of the examples is presented in (1).

(1) ST : Although the site escaped detection by the Spaniards, it may have been visited by the German adventurer Augusto Berns in 1867. 


\section{TT : Meskipun situs tersebut tidak terdeteksi oleh orang-orang Spanyol, situs itu mungkin telah dikunjungi oleh petualang Jerman Augusto Berns pada tahun 1867.}

The SL interference is obvious when the student translator keeps the ST structure in the TT. The ST is a complex sentence, and so is the TT. The decision to keep the ST structure results in using the repetition of the same subject "situs itu". The repetition is due to the absence of established equivalence of the word "it" as the subject in the TL. Although "it" as the subject literally means "dia" in the TL, it should refer only to human. To avoid such repetition, deletion technique may be applied. As the two clauses have the same subject, one of the subjects (the subject in the first clause) can be omitted. In addition, the SL interference is visible when the student translator writes "petualang Jerman Augusto Berns" as the equivalent of "the German adventurer Augusto Berns". Although such translation represents the original meaning contained in the ST, such structure is awkward in the TL. Generally, the phrase "yang bernama" is inserted between the title "the German adventurer" and the person's name "Augusto Berns". Furthermore, the word "seorang" can be added in order to show that the ST informs only one German adventurer may have visited the site. The translation in (1) can be improved as in (1a).

(1a) Meskipun tidak terdeteksi oleh orang-orang Spanyol, situs itu mungkin telah dikunjungi oleh seorang petualang Jerman yang bernama Augusto Berns pada tahun 1867.

The other SL interference found in the translation of student translators can be seen in (2).

(2) ST : Technology in the 21 st-century, however, identified a significant proportion of males and a great diversity in physical types.

TT : Teknologi pada abad ke-21, bagaimanapun juga, mengidentifikasi proporsi signifikan laki-laki dan keberagaman bentuk fisik.

The SL interference in (2) is found in the use of conjunction "bagaimanapun juga" (as the equivalent of "however") that interrupts the sentence in the TT. In the TL, such contrast conjunction is used only in the beginning of a sentence or a clause, and it is never used to interrupt the elements of a sentence or a clause. Therefore, it is easily identified that the use of contrast conjunction "bagaimanapun juga" that interrupts the TT sentence in (2) is influenced by the SL structure.

The second equivalence problem found in the translation of the student translators is misunderstanding of the ST mainly caused by their insufficient knowledge of the SL structure. One of the main SL structure problems encountered by the student translators is a phrase structure, particularly in defining the modifier(s) in a phrase. Study the translation of the phrase in (3).

(3) ST : ... a local Quechua speaking resident

$$
\text { TT : ... penutur bahasa lokal Quechua }
$$

The ST in (3) is a noun phrase (NP) composed of "local" (adjective) as the modifier and the remaining is the core. The translation problem arises in identifying which elements are modified by the modifier "local" because the core is composed of another NP "Quechua speaking resident". In the SL structure, the core of NP composed of several nouns is the noun appearing in the final position; therefore, the core should be "resident". However, the TT indicates that the word "local" modifies "Quechua", one of the local languages in Peru. The student translator's insufficient knowledge of the modifier and the core of the phrase makes the TT in (3) fail to represent the meaning contained in the ST; in other words, the TT is not the right equivalent of the ST. Such failure certainly results in inaccurate translation. 
In addition, the equivalence problem related to misunderstanding of the ST is found in translating the phrase as in (4).

(4) ST : Machu Picchu, also spelled Machupijchu, ...

TT : Machu Picchu, yang juga disebut Machupijchu, ...

The translation problem shown in (4) occurs when the student translator misunderstands the ST word "spelled". This problem is caused by the different characteristics of the TL and SL. The TL is a phonetic language, while the SL is not [22]; therefore, spelling is not well recognized by TL speakers. The use of ST word "disebut" as the equivalent of the ST word "spelled" is not precise since "disebut" is related to "pronunciation", while the ST original meaning is related to "orthography".

The third equivalence problem found in the translation of the student translators is the improper use of borrowing technique. Although borrowing is one of the translation techniques mentioned in a number of studies (e.g. [5]; [23]; [24]; [25]), it should be used when there is no established equivalence available in the TL. Study the example of incorrect borrowing in (5).

(5) ST : It is perched above the Urubamba River valley in a narrow saddle between two sharp peaks

TT : Machu Picchu terletak di atas lembah Sungai Urubamba di sadel yang sempit antara dua puncak yang tajam

The incorrect use of a borrowing technique in the translation in (5) is indicated by the underlined words. The borrowing was done by naturalizing the ST word "saddle" into "sadel", the acceptable SL spelling. Even though the word "sadel" is used in the TL, its meaning does not represent the meaning of "saddle" in the ST. According to the Monolingual Indonesian Dictionary, "sadel" means a seat on horse or on a bicycle, while the meaning of "saddle" in the ST is a space. So, the use of "sadel" in the context of translation in (5) indicates the use of incorrect equivalence.

The other equivalence problem related to the incorrect use of borrowing technique found in the translation of the student translators is shown in (6).

(6) ST : ... which were sponsored by Yale University and the National Geographic Society

TT : ... yang disponsori oleh Universitas Yale dan National Geographic Society

The problem of equivalence occurs when the student translator decided to borrow the ST phrase "National Geographic Society" in the TT. As the initial letters of each of the words are capitalized, the student translator simply regards it as the proper name, which is usually unchangeable in translation. However, it is not a proper name as it is the name of organization which is usually translated into certain target languages. In the context of bahasa Indonesia as the TL, the right and widely used equivalent for such organization is "masyarakat geografi nasional'.

The fourth equivalence problem in the translation of the student translators is related to meaning deletion as in (7).

(7) ST : ... however, that interpretation is no longer widely accepted.

TT : ... namun, interpretasi itu tidak diterima secara luas.

Meaning deletion in the translation in (7) shows that the TT is not equivalent in meaning with the ST. The student translator decides to delete the meaning carried out by the ST word "longer" in the TT, and such deletion certainly leads to changes in the original meaning contained in the ST. The TT in (7) saying that "the interpretation is not widely accepted" means that the interpretation has never been widely accepted. Meanwhile, the ST originally means that the interpretation used to be accepted, but it is not accepted anymore nowadays. Deletion is only allowed when the original meaning is comprehensively conveyed in the TT. 
The deletion-related equivalence problem found in the translation of the student translators can also be seen in (8).

(8) ST : One of the few major pre-Columbian ruins found nearly intact, Machu Picchu was designated a UNESCO World Heritage site in 1983.

TT : Sebagai reruntuhan bangunan pada masa pra-Kolombia yang ditemukan hampir utuh, Machu Picchu ditetapkan sebagai situs Warisan Dunia UNESCO pada tahun 1983.

The ST in (8) means that Machu Picchu is one of the few major pre-Columbian ruins found nearly intact; however, the TT means that Machu Picchu is the only major preColumbian ruin, showing that the meaning contained in the ST is partially deleted in the TT. Such deletion influences the TL readers' understanding of the pre-Columbian ruins found nearly intact.

The fifth equivalence problem is lack of TL competence. A good translator must have good competence in both the SL and the TL. As the student translators are Indonesian students, the TL competence in this context refers to the language competence in bahasa Indonesia. In translation, competence as the person's knowledge of his/her language [26] influences the use of the linguistic code of a language [27] in the TT. In other words, the translators' competence of the TL is reflected in their TT. The translation in (9) presents the student translator's lack of TL competence.

(9) ST : The dwellings at Machu Picchu were probably built and occupied from the mid- $15^{\text {th }}$ to the early or mid- $16^{\text {th }}$ century.

TT : Rumah di Machu Picchu mungkin dibangun dan ditempati dari pertengahan abad 15 hingga awal atau pertengahan abad 16.

The TT in (9) sounds strange to TL readers due to several problems. First, the word "dwellings" in the ST indicates plural nouns, but its equivalent in the TT is in the form of singular noun. Although English plurals should not always be translated plurals in bahasa Indonesia [28], the context of the translation in (9) requires "dwellings" to be translated in a TL plural form. Referring to the prevailing TL structure, plurals are formed through reduplication; consequently, the right equivalent of "dwellings" is "rumah-rumah". Second, the decision to use "dari" as the equivalent of the ST word "from" is not appropriate because it forms a "from ... to" prepositional phrase structure. In the TL, such phrase structure is equivalent with "sejak ... hingga" structure in the TL. Finally, the student translator's lack of TL competence is found in providing the equivalence of SL ordinal numbers. The ordinal numbers $15^{\text {th }}$ and $16^{\text {th }}$ in the ST are translated in cardinal numbers (15 and 16) in the TT. In the TL, such ordinal numbers should be equivalent with "ke-15" and "ke-16". Thus, the TT in (9) can be improved as in (9a).

(9a) Rumah-rumah di Machu Picchu mungkin dibangun dan ditempati sejak pertengahan abad ke-15 hingga awal atau pertengahan abad ke-16.

As a matter of fact, the student translators' insufficient TL competence can be solved by having online resources management skill, precisely utilizing Internet facilities. Internet provides a variety of online resources helpful to cover up their weaknesses in the TL competence. Online nationally reputable newspapers, online Indonesian monolingual dictionary, and the website of Language Development, the Ministry of Education and Culture of Republic of Indonesia are several online resources serving as the useful references of the prevailing spelling and structure of the TL [29].

Translator's lack of vocabulary stock, which used to be a translation problem in finding equivalence, does no longer present a problem to the student translators. In this study, the student translators were allowed to use any online resources, and they can easily solve such 
problem by using online dictionaries or online machine translation. This is corresponding to the issue of the role of human as a post-editor in translation process.

\section{Conclusions and Suggestion}

Based on the results of the study, it is concluded that SL interference, ST misunderstanding, improper use of borrowing technique, meaning deletion and insufficient TL competence are the equivalence-related problems encountered by student translators in translating a historical recount text from English into bahasa Indonesia. SL interference is obviously seen in the student translators' TT that tends to follow the SL style and structure; ST misunderstanding is caused by the student translators' insufficient knowledge of the SL structure and the different characteristics of the SL and TL; improper use of borrowing technique is caused by the issue of non-equivalent terms; meaning deletion is mainly due to improper generalization; and insufficient TL competence is mainly caused by the student translators' TL proficiency and inability to utilize online resources. This study presents several equivalence problems in translation, so it is suggested for further researchers to conduct a study on possible solutions to solve such problems.

\section{Acknowledgments}

The authors would like to thank the Research Institute of Universitas Negeri Padang for funding this research.

\section{References}

[1] T. D. Andersen,"Perceived authenticity: The fourth criterion of good translation," Notes on Translation, vol. 12, no. 3, pp. 1-13, 1998.

[2] M. O. L. Almutairi M O L , The objectivity of the two main academic approaches of translation quality assessment: Arab spring presidential speeches as a case study. Leicester: University of Leicester, 2018

[3] B. Mossop, Revising and editing for translators. Manchester, UK: St. Jerome Publishing, 2001.

[4] R. Sofyan and B. Tarigan B,'Developing a holistic model of translation quality assessment," Advances in Social Science, Education and Humanities Research, vol. 254, no. 1, pp. 266-271, 2019

[5] P. Newmark P, A textbook of translation. New York: Prentice Hall, 1988.

[6] H. Vossoughi and M. R. Ghelichkhani,"Componential analysis and translation accuracy," Iranian Journal of Applied Linguistics, vol. 1, no. 1, pp. 69-82, 1996.

[7] Y. Chen-chen and L. Jin-zhu L ,"The functions of componential analysis to the translation of cultural animal images in The Classic of Mountains and Seas," Sino-US English Teaching, vol.13, no. 9, pp. 724-735, 2016.

[8] T. Baldwin and H. Tanaka,"Balancing up efficiency and accuracy in translation retrieval," Journal of Natural Language Processing, vol.8, no. 2, pp. 19-37, 2001.

[9] M. Aiken, K. Ghosh, J. Wee , and M. Vanjani,"An evaluation of the accuracy of online translation systems Communications of the IIMA," vol. 9, no. 4, pp. 67-84, 2009. 
[10] M. Aiken and S. Balan ,"An analysis of Google Translate accuracy," Translation Journal, vol. 16, no. 2, 2011.

[11] J. C. Catford, A linguistic theory of translation. London: Oxford University Press, 1965.

[12] D. Panou,"Equivalence in translation theories: a critical evaluation," Theory and Practice in Language Studies, vol. 3, no. 1, pp. 1-6, 2013

[13] N. A. D. M. Alfaori,"Equivalence problems in translation," Sino-US English Teaching, vol. 14, no. 2, pp. 86-97, 2017

[14] V. Leonardi,"Equivalence in translation: Between myth and reality," Translation Journal, vol. 4, no. 4, 2000.

[15] M. Krein-Kuhle M, Equivalence in scientific and technical translation: A text-incontext-based study. Salford: University of Salford, 2003.

[16] X. Yinhua,"Equivalence in translation: Features and necessity," International Journal of Humanities and Social Science, vol. 1, no. 10, pp. 169-171, 2011.

[17] A. D Kashgary,"The paradox of translating the untranslatable: Equivalence vs. nonequivalence in translating from Arabic into," English Journal of King Saud University -Languages and Translation, vol. 23, no.1, pp. 47-57, 2010.

[18] M. J. Moafi,"Equivalency and non-equivalency of lexical items in English translations of nahj al-balagha," Religious Inquiries, vol. 4, no. 8, pp. 39-48, 2015.

[19] T. Andreici,"Translation of phrasemes, equivalence and non-equivalence,"Professional Communication and Translation Studies, vol. 9, pp. 153-166, 2016.

[20] M. A. K. Herlambang, A study of translation equivalence and acceptability on the subtitle of Intel advertisements. Yogyakarta: Sanata Dharma University, 2017.

[21] R. N Rosa, T. S. Sinar, Z. Ibrahim-Bell and E. Setia,"Pauses by student and professional translators in translation process," International Journal of Comparative Literature and Translation Studies, vol. 6, no. 1, pp. 18-28, 2018

[22] A. Khalilzadeh," Phonetic and non-phonetic languages: A contrastive study of English and Turkish phonology focusing on the orthography-induced pronunciation problems of Turkish learners of English as a foreign language (Turkish EFL learners)," International Journal of Languages' Education and Teaching, vol. 2, no.1, pp. 1-16, 2014.

[23] M. Baker, In other word: A course book on translation. London: Longman, 1992.

[24] L. Molina and A. A. Hurtado,"Translation techniques revisited: A dynamic and functionalist approach," Meta, vol. 47, no. 4, pp. 498-512, 2002

[25] L. D'hulst,Translation history Handbook of translation studies eds Y Gambier and L van Doorslaer. Amsterdam: John Benjamins Publishing Company, 2010

[26] N. Chomsky, Aspects of the theory of syntax. Cambridge: MIT Press, 1965.

[27] D. Newby,"Competence and performance in learning and teaching: theories and practices," Selected Papers from the 19th ISTAL pp 15-32, 2011

[28] Y. A. Alzuhdy,"Analisis translation shift dalam penerjemahan bilingual bahasa Inggris - bahasa Indonesia," Diksi, vol. 22 no. 2, pp. 185-193, 2014

[29] R. Sofyan and B. Tarigan,"Online resources management in self-corrections and translation quality," International Journal of Sciences: Basic and Applied Research vol. 35 no.2, pp. 212-224, 2017. 